\title{
Response of arbuscular mycorrhizal fungi and phosphorus solubilizing bacteria to remediation abandoned solid waste of coal mine
}

\author{
Yinli $\mathrm{Bi}^{1}{ }^{1} \cdot \mathrm{Li} \mathrm{Xiao}^{1} \cdot$ Rongrong Liu $^{1}$
}

Received: 13 April 2019/Revised: 3 July 2019/Accepted: 24 August 2019/Published online: 10 September 2019

(C) The Author(s) 2019

\begin{abstract}
Coal is the vital resource of energy in China, but abandoned coal ash and gangue lead to the degradation of vegetation cover and reduce soil quality. Both arbuscular mycorrhizal fungi (AMF) and phosphate solubilizing bacteria (PSB) play a key role in biogeochemical cycle such as soil organic matter decomposition, nutrition release, and energy flow. To improve and reclamation the soil quality and ecological efficiency of the coal mining waste, we investigated the effects of an AMF strain (Glomus mosseae) and a PSB strain (Pantoesstewarti) on phytate mineralization and subsequent transfer to the host plant (Medicago sativa L.) using a two-compartment microcosm with a central $30 \mathrm{~mm}$ nylon mesh barrier. The results showed that significantly higher available P (AP), above ground biomass (AGB) and underground biomass (UGB) were in combined inoculation of AMF-PSB than other treatments in root and hyphae compartment. The microbial inoculum of the AMF or PSB had a significant influence on soil acid phosphatase activities (ACP). AMF-PSB enhanced phytate mineralization, improved plant biomass. AP and ACP positively influenced the AGB and UGB. AMFPSB could be used as bioinoculant to enhance sustainable production of the plant in abandoned solid waste of coal mine.
\end{abstract}

Keywords Arbuscular mycorrhizal fungi $\cdot$ Phosphorus solubilizing bacteria $\cdot$ Abandoned solid waste $\cdot$ Ecological reclamation $\cdot$ Coal mine

\section{Introduction}

Coal is the vital resource of energy in China (Lam 2005), which had great contributions to the economic and social development for many years (Liu and Diamond 2005; Miao and Marrs 2000). However, coal mine lead to the degradation of vegetation cover and reduced soil quality activities, especially abandoned coal mine with coal ash and gangue damage soil physicochemical property and disrupt local ecosystems (Mukhopadhyay et al. 2016; Bi et al. 2018). In addition, abandoned coal mine often has adverse effect on biodiversity of the affected area and soil

Yinli Bi

ylbi88@126.com

1 State Key Laboratory of Coal Resources and Safe Mining, China University of Mining and Technology (Beijing), Beijing 100083, China moisture, leading to land degradation (Mukhopadhyay et al. 2014). Meanwhile, the influence of abandoned coal mine on social and economic facilities is a growing concern due to rapid urbanization and industrialization in China. Site recovery, which could restore soil fertility and increase biodiversity, play an important role in controlling the soil erosion and land degradation in the abandoned coal site (Singh and Singh 2006). People also studied and vegetation coverage change and stability in large open-pit coal mine dumps in China during 1990-2015 (Liu et al. 2016) and re-vegetation types improve soil enzyme activities and microbial biomass in coal mining subsidence areas of Northern China (Xiao et al. 2019). Nevertheless, how to sustainably and rapidly improve and reclamation the soil quality and ecological efficiency of the coal mining waste is unclear but vital for current society with rapid urbanization and industrialization. 
Soil microorganisms, an important component of soil ecosystem, play a key role in biogeochemical cycle such as soil organic matter decomposition, nutrition release, and energy flow (Bell et al. 2005; Zeng et al. 2017; Zhang et al. 2017). Arbuscular mycorrhizal fungi (AMF) are obligate symbionts of plants that are associated with the roots of more than $80 \%$ vascular land plants, which significantly enhances long-term success of mine site reclamation (Levy and Cumming 2014). Previous studies showed that AMF were useful for building a productive, healthy, and sustainable land ecosystem with vegetation cover. Previous studies found that rhizosphere microbial processes had diverse effects on performance of the planted tree and plant community succession promoted reclaimed soil fertility in degraded coal mining area (Sinha et al. 2009; Pedrol et al. 2010). Meanwhile, AMF are able to release protons to mobilize insoluble soil phosphates, extend their extensive hyphae from the phosphorus depletion zone to explore a greater soil volume for inorganic $\mathrm{P}$ sources (Smith and Smith 2011). Previous studied found that AMF alleviate root damage stress induced by simulated coal mining subsidence ground fissures (Bi et al. 2019b) and increase plant diversity in mining land remediation ( $\mathrm{Bi}$ and Shen 2019). $P$ is the second most important macronutrient in plants after nitrogen, as it plays an important role in energy transfer, cell division, photosynthesis, biological oxidation, metabolism, and reproduction (Sashidhar and Podile 2010). Phosphate solubilizing microorganisms mobilize insoluble phosphates in the soil and increase plant growth under conditions of poor $\mathrm{P}$ availability (Tripura et al. 2007). The relationship between phosphate solubilizing bacteria (PSB) and plants is synergistic in nature, as bacteria provide soluble phosphate and plants supply root borne carbon compounds (mainly sugars) that can be metabolized for bacterial growth (Pérez et al. 2007). PSB can increase soil available $\mathrm{P}$ through the release of organic acids and phosphatases, which enhances the mineralization of organic P sources (Rodríguez and Fraga 1999). Research found that PSB could achieve the effective use of coal fly ash in the mine reclamation (Bi et al. 2008). Meanwhile, through the development of vegetation and plants, mutualistic fungal and bacterial associations have provided key metabolites (e.g. phosphorus, nitrogen, microelements) to their hosts, and thereby play a major role in plant colonization in terrestrial ecosystems (Barker et al. 2017).

AMF and PSB are two key beneficial functional groups that are directly involved in $\mathrm{P}$ turnover and subsequent plant $P$ acquisition (Zhang et al. 2014). Previous studies have shown positive effects of dual inoculation with AMF and PSB on increasing PSB numbers on root surfaces (Andrade et al. 1998), mycorrhizal colonization rates (Sabannavar and Lakshman 2009), and AMF hyphal promoting phosphatase activity (Mar Vázquez et al. 2000; Kohler et al. 2007). However, few studies focused on the effects of AMF and PSB on the abandoned solid waste of coal mine. The aim of the present study was to discuss whether AMF and PSB can improve the soil quality of abandoned coal mine waste. We hypothesized that AMF or PSB can (1) improve soil quality, soil moisture of abandoned coal mine waste, (2) the combination of AMF and PSB had more effective on facilitating soil nutrient and the utilization of organic $\mathrm{P}$ by plants as PSB will convert organic $\mathrm{P}$ to available $\mathrm{P}$. The results could provide baseline data for applying the biological reclamation effects of AMF-PSB on abandoned solid of coal mining.

\section{Method and material}

\subsection{Biological materials}

The host plant used was Medicago sativa L., which had a relatively small biomass at the seedling stage and AMF could symbionts with the roots. The AMF strain Funneliformis mosseae, kindly provided by Beijing Academy of Agriculture and Forestry, is a widely studied strain that has often been used as a model AM fungus and propagated at China University of Mining and Technology (Beijing) (Bi et al. 2019a). The phosphorus solubilizing bacteria strain used was Pantoesstewarti, which was isolated from the coal ash of Ningxia Autonomous Region in the microbial reclamation laboratory of China University of Mining \& Technology, Beijing. General primers (the primers were $27 \mathrm{~F}$ and $1492 \mathrm{R}$ ) of $16 \mathrm{~S}$ rDNA were used for PCR amplification of the bacteria gene (Bi 2008). The Sequence of the PCR product was compared with BLASTN in the GenBank database, and the bacteria strain was determined as Pantoesstewarti.

\subsection{Experiment design and management}

Two-compartment microcosms were constructed to meet the experimental requirements (Fig. 1). Each microcosm was comprised of a $5 \mathrm{~cm} \times 10 \mathrm{~cm} \times 15 \mathrm{~cm}$ $(l \times h \times w)$ root compartment $(\mathrm{RC})$ and a $3 \mathrm{~cm} \times 10$ $\mathrm{cm} \times 15 \mathrm{~cm}$ hyphae-only compartment (HC). The two compartments were separated from each other by a $30 \mu \mathrm{m}$ nylon mesh. Thus, the soils in the two sections were referred to as root soil and hyphae soil (Fig. 1). Moderately acid ( $\mathrm{pH}=7.26$ ) river sand soil was used as the growth medium for root compartment and a mixture of coal ash and gangue (from Ningxia Autonomous Region) at a ratio of 6:1 was used as the soil for hyphae-only compartment. The "soils" were passed through a 1-mm sieve, sterilized at high temperature and pressure $\left(121^{\circ} \mathrm{C}, 103 \mathrm{kP}\right)$ for $2 \mathrm{~h}$, and air-dried. The levels of fertilizers for root compartment 


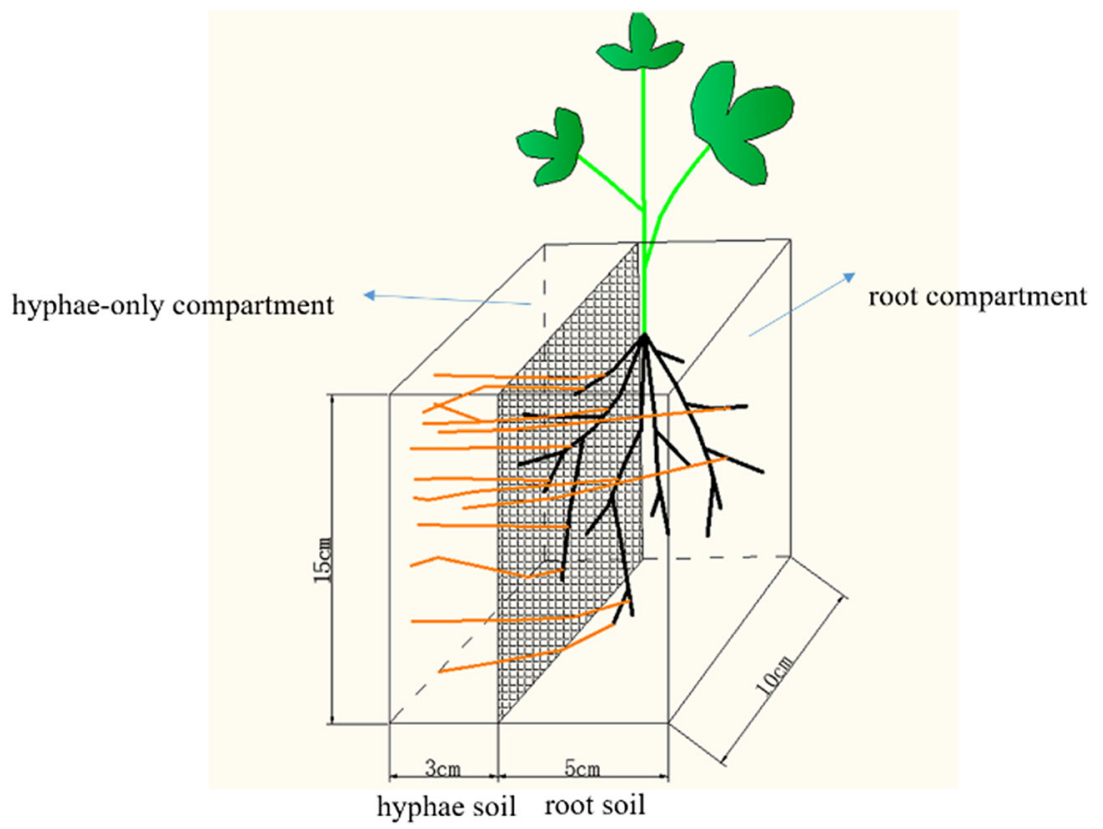

Fig. 1 Two-compartment microcosms

were $\mathrm{N}\left(\mathrm{NH}_{4} \mathrm{NO}_{3}\right) 10 \mathrm{mg} / \mathrm{kg}, \mathrm{P}\left(\mathrm{KH}_{2} \mathrm{PO}_{4}\right) 2.5 \mathrm{mg} / \mathrm{kg}$ and $\mathrm{K}\left(\mathrm{KNO}_{3}\right) 15 \mathrm{mg} / \mathrm{kg}$.

In the root soil compartment, Medicago sativa $\mathrm{L}$. seeds that were treated with $10 \%$ hydrogen peroxide for $10 \mathrm{~min}$ were planted and grew for 60 days after germination. The experiment contained three treatment groups: (1) PSB were added to the hyphae-only compartment (-M/CA); (2) AMF were added to the root compartment $(+\mathrm{M} / \mathrm{CK})$; (3) $\mathrm{AMF}$ were added to the root soil and PSB were added to the hyphae soil (+M/CA); (4) Plants grown in two-compartment microcosm without the addition of fungus and bacteria were used as the control $(-\mathrm{M} / \mathrm{CK})$. Each treatment had three replicates. Plants in these microcosms were grown in a campus greenhouse at China University of Mining \& Technology, Beijing. The plants and soils were harvested after growth for 60 days. The roots and shoots of each plant were separated, and their dry weights were recorded after oven drying at $75{ }^{\circ} \mathrm{C}$. Rhizosphere soil samples were removed roots, stones and animals for basic physical and chemical properties.

\subsection{Measurement of parameters}

Soil $\mathrm{pH}$ was measured using a $\mathrm{pH}$ meter after shaking the soil water $(1: 5 \mathrm{w} / \mathrm{v})$ suspension for $30 \mathrm{~min}$. Soil water content was determined by oven-drying to constant mass at $105^{\circ}$. Soil available phosphorus (AP) was extracted by $0.5 \mathrm{~mol} / \mathrm{L} \mathrm{NaHCO}_{3}$ and measured by molybdenum-blue method (Olsen et al. 1982). Acid phosphatase activity ( $\mu \mathrm{g}$ p-nitrophenyl phosphate $\min ^{-1} \mathrm{~g}^{-1}$ DW soil) in the hyphae soil was determined according to Zhang et al. (2014).
Mycorrhizal colonization of roots was measured using the reported method (Trouvelot et al. 1986). External mycorrhizal hyphae were extracted from two $5 \mathrm{~g}$ soil sub-samples from the hyphae soil compartment using the membrane filter technique (Staddon et al. 2010). Hyphal length was assessed using the gridline intercept method at $200 \times$ magnification and then converted to hyphal length density ( $\mathrm{m} / \mathrm{g}$ DW soil). The amount of soil fungi and bacteria were determined by plate count method (Hattori 1985).

\subsection{Data analysis}

All results were reported as mean \pm standard error. Oneway ANOVA, Student's $t$ test, and S-K-N multiple range comparison were used to compare the significant effects among crops using the IBM SPSS 18.0 software program (SPSS Inc., USA). The figures were adopted with origin 9.0. The non-metric multi-dimensional scaling (NMDS) was used with Primer 7. The spearman correlation analysis was performed to show the relationships between the soil microbial activity and soil physicochemical properties with $\mathrm{R}$ (3.4.1) for windows.

\section{Results}

\subsection{Physicochemical properties and biomass}

As shown in Table 1, all soil $\mathrm{pH}$ was neutral or weak acid, ranging from 6.82 to 7.68 . Significantly higher AP, AGB 
Table 1 Physicochemical properties and biomass

\begin{tabular}{llllllr}
\hline Item & Compartment & $\mathrm{pH}$ & $\mathrm{MS}$ & $\mathrm{AP}(\mathrm{mg} / \mathrm{kg})$ & AGB $(\mathrm{g})$ & $\mathrm{UGB}(\mathrm{g})$ \\
\hline$-\mathrm{M} / \mathrm{CK}$ & $\mathrm{RC}$ & $7.46 \pm 0.02 \mathrm{~b}$ & $0.03 \pm 0.00 \mathrm{~b}$ & $0.91 \pm 0.06 \mathrm{~b}$ & $0.28 \pm 0.01 \mathrm{c}$ & $0.10 \pm 0.01 \mathrm{c}$ \\
& $\mathrm{HC}$ & $6.82 \pm 0.23 \mathrm{a}$ & $0.35 \pm 0.05 \mathrm{a}$ & $5.05 \pm 0.20 \mathrm{c}$ & & \\
$-\mathrm{M} / \mathrm{CA}$ & Root & $7.59 \pm 0.05 \mathrm{~b}$ & $0.04 \pm 0.00 \mathrm{a}$ & $1.15 \pm 0.07 \mathrm{~b}$ & $0.34 \pm 0.04 \mathrm{~b}$ & $0.13 \pm 0.00 \mathrm{~b}$ \\
& Hyphae & $6.92 \pm 0.07 \mathrm{a}$ & $0.31 \pm 0.05 \mathrm{ab}$ & $6.33 \pm 0.45 \mathrm{~b}$ & & \\
$+\mathrm{M} / \mathrm{CK}$ & Root & $7.67 \pm 0.03 \mathrm{a}$ & $0.02 \pm 0.01 \mathrm{~b}$ & $0.90 \pm 0.07 \mathrm{~b}$ & $0.33 \pm 0.03 \mathrm{~b}$ & $0.12 \pm 0.02 \mathrm{~b}$ \\
& Hyphae & $6.82 \pm 0.06 \mathrm{a}$ & $0.24 \pm 0.01 \mathrm{~b}$ & $5.78 \pm 0.21 \mathrm{~b}$ & & $0.39 \pm 0.01 \mathrm{a}$ \\
+ M/CA & Root & $7.68 \pm 0.03 \mathrm{a}$ & $0.04 \pm 0.02 \mathrm{a}$ & $1.53 \pm 0.33 \mathrm{a}$ & $0.16 \pm 0.02 \mathrm{a}$ \\
& Hyphae & $6.89 \pm 0.16 \mathrm{a}$ & $0.29 \pm 0.08 \mathrm{ab}$ & $6.93 \pm 0.23 \mathrm{a}$ & & \\
\hline
\end{tabular}

Note $R C$ root compartment, $H C$ hyphae compartment, $M S$ moisture, $A P$ available phosphorus, $A G B$ above-ground biomass, $U G B$ under-ground biomass, different lowercase letters in each column refer to significant differences among treatments in the same compartment $(P<0.05)$, the same below

and UGB were found in $+\mathrm{M} / \mathrm{CA}$. The levels of AP, AGB, and $\mathrm{UGB}$ in the four groups were $+\mathrm{M} / \mathrm{CA}>+\mathrm{M} /$ $\mathrm{CK} \approx-\mathrm{M} / \mathrm{CA}>-\mathrm{M} / \mathrm{CK}$, with similarity regulation between root compartment (root) and hyphae compartment (hyphae). The content of AP in +M/CA was $6.93 \mathrm{mg} / \mathrm{kg}$ and $1.53 \mathrm{mg} / \mathrm{kg}$ in root and hyphae, respectively, which were 1.37 and 1.68 times of those in $-\mathrm{M} / \mathrm{CK}$.

\subsection{Soil biological properties}

The details of the hyphae density, the rate of mycorrhizal colonization and acid phosphatase were presented in Fig. 2. We found that PSB significantly increased the hyphae density of AMF (Fig. 2a). The value of hyphae density was 0.81 and $0.65 \mathrm{~m} \mathrm{~g}^{-1}$ in root compartment and hyphae compartment in $+\mathrm{M} / \mathrm{CA}$, which was about twice as much as those in the $+\mathrm{M} / \mathrm{CK}$. The rate of mycorrhizal colonization in the $+\mathrm{M} / \mathrm{CK}$ and $+\mathrm{M} / \mathrm{CA}$ were 0.48 and 0.31 , with significant variations between different isolates $(P<0.05)$ (Fig. 2b). The microbial inoculum of the AMF and PSB had a significant influence on soil acid phosphatase activities (Fig. 2c). In the hyphae compartment, soil acid phosphatase activities were found to be significantly higher in groups containing AMF and/or PSB (+M/ $\mathrm{CA}>-\mathrm{M} / \mathrm{CA}>+\mathrm{M} / \mathrm{CK}>-\mathrm{M} / \mathrm{CK}$ ), ranging from 1.46 to $1.61 \mu \mathrm{g}^{-1} \mathrm{~g}^{-1} \mathrm{~h}^{-1}$. Soil acid phosphatase activities in the root compartment soil showed a similar trend as that in the hyphae compartment, but had the lowest value in $-\mathrm{M} /$ CK. One-way ANOVA analysis results indicated that the amount of soil fungi and bacteria were principally affected by AMF and PSB (Table 2). The amount of soil fungi and bacteria were significantly higher in $+\mathrm{M} / \mathrm{CA}$ and lower in $-\mathrm{M} / \mathrm{CK}$ both in root and hyphae compartments, with the rank of $+\mathrm{M} / \mathrm{CA}>-\mathrm{M} / \mathrm{CA}>+\mathrm{M} / \mathrm{CK}>-\mathrm{M} / \mathrm{CK}$.
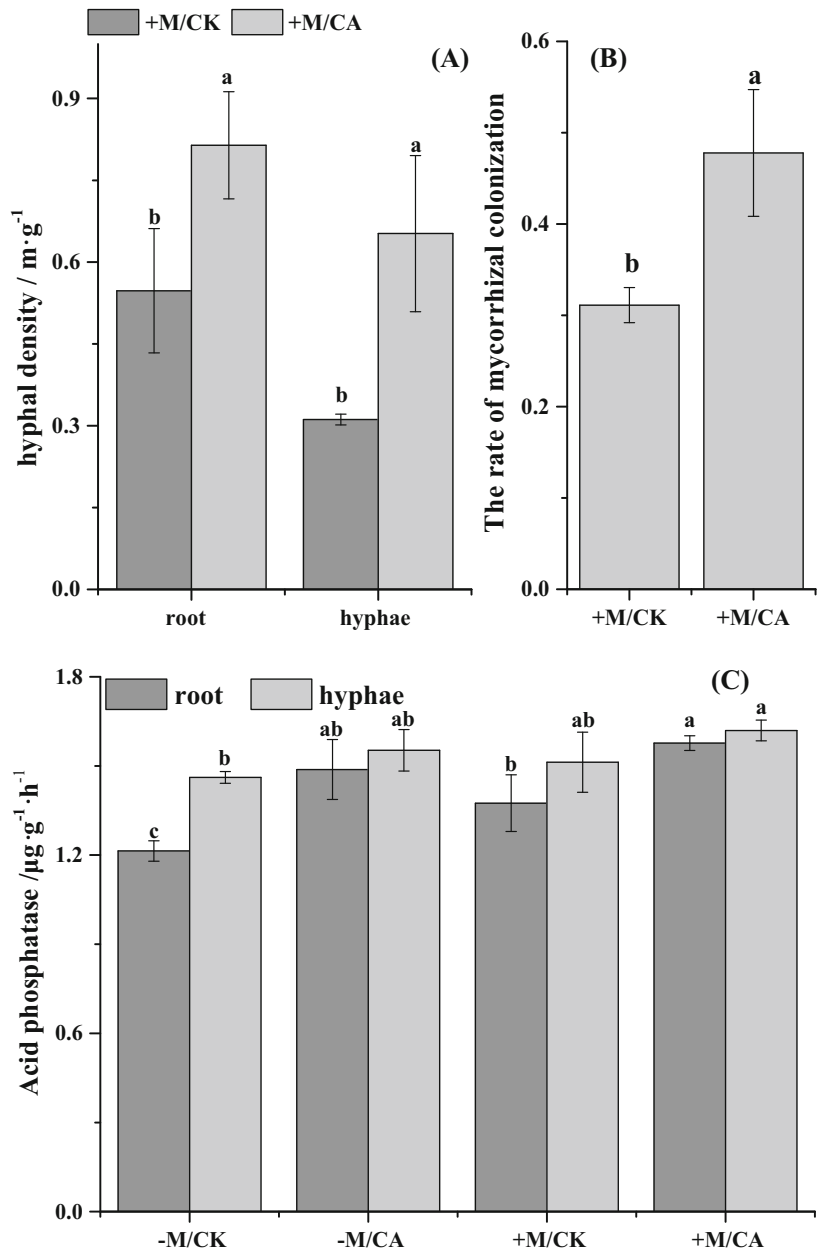

Fig. 2 Hyphae density (a), the rate of mycorrhizal colonization (b) and soil acid phosphatase (c) under different treatments. Note: different lowercase letters refer to significant difference among treatments in the same compartment $(p<0.05)$ 
Table 2 The amount of soil fungi and bacteria

\begin{tabular}{llllr}
\hline Item & \multicolumn{2}{l}{ Fungi amount $10^{3} \mathrm{CFU} \mathrm{g}^{-1}$} & & \multicolumn{2}{l}{ Bacteria amount $10^{6} \mathrm{CFU} \mathrm{g}$} \\
\cline { 2 - 3 } & Root & Hyphae & Root & Hyphae \\
\hline$-\mathrm{M} / \mathrm{CK}$ & $1.55 \pm 0.24 \mathrm{c}$ & $4.14 \pm 0.80 \mathrm{~b}$ & $0.79 \pm 0.26 \mathrm{a}$ & $9.81 \pm 1.12 \mathrm{c}$ \\
$-\mathrm{M} / \mathrm{CA}$ & $3.07 \pm 1.09 \mathrm{ab}$ & $9.16 \pm 4.93 \mathrm{a}$ & $1.58 \pm 0.98 \mathrm{a}$ & $16.78 \pm 4.82 \mathrm{ab}$ \\
$+\mathrm{M} / \mathrm{CK}$ & $1.94 \pm 0.83 \mathrm{bc}$ & $8.77 \pm 1.43 \mathrm{a}$ & $1.18 \pm 0.69 \mathrm{a}$ & $13.18 \pm 4.37 \mathrm{bc}$ \\
$+\mathrm{M} / \mathrm{CA}$ & $3.15 \pm 1.15 \mathrm{a}$ & $12.50 \pm 4.64 \mathrm{a}$ & $1.78 \pm 1.30 \mathrm{a}$ & $21.06 \pm 3.09 \mathrm{a}$ \\
\hline
\end{tabular}

\subsection{Relationship among the treatments and soil parameters}

The non-metric multi-dimensional scaling (NMDS) of soil parameters and biological properties among different treatments was presented in Fig. 3. Different treatments took the formation of four distinguishing clusters, indicating that soil parameters had a significant composition among the four treatments. The spearman correlation analysis was used to demonstrate the relationship between physicochemical and biological properties (Fig. 4). Correlation matrix analysis of soil properties revealed that R-AP, $\mathrm{H}-\mathrm{AP}, \mathrm{R}-\mathrm{ACP}$ and H-ACP positively influenced the AGB and UGB. As a result, soil acid phosphatase activities (H$\mathrm{ACP}$ and $\mathrm{R}-\mathrm{ACP}$ ) were significantly and positively correlated with H-AP and R-AP. Meanwhile, R-pH had a significant positive correlation with AGB and UGB. However, $\mathrm{H}-\mathrm{pH}$ had a negative correlation with H-ACP.

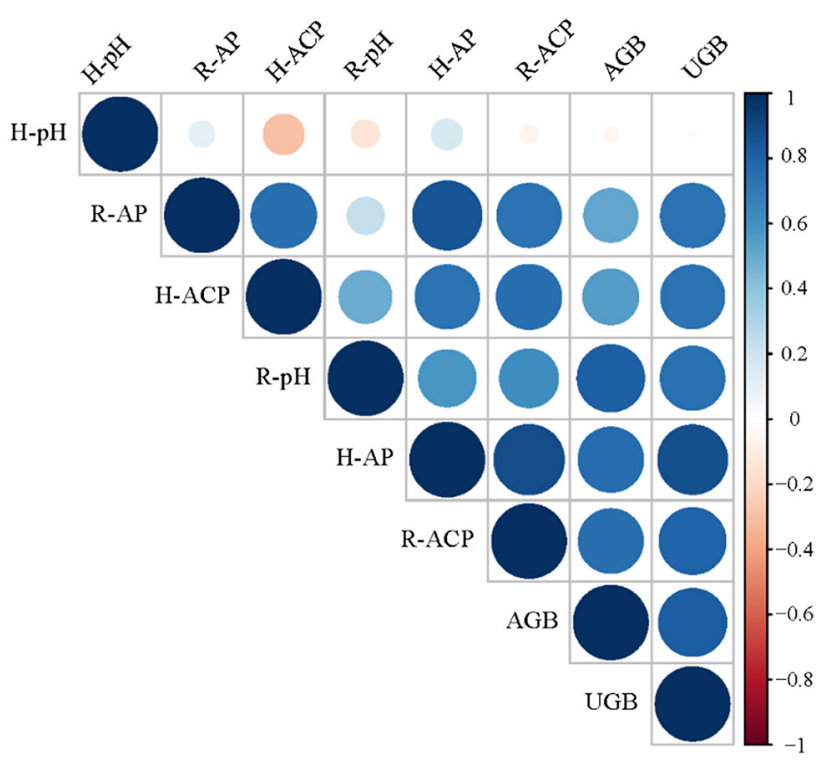

Fig. 4 The spearman correlation analysis between physicochemical and biological properties. Note: the prefix capital letter of $\mathrm{H}$ : hyphae compartment; the prefix capital letter of R: root compartment; $A P$ available phosphorus, $A C P$ acid phosphatase, $A G B$ aboveground biomass, $U G B$ underground biomass

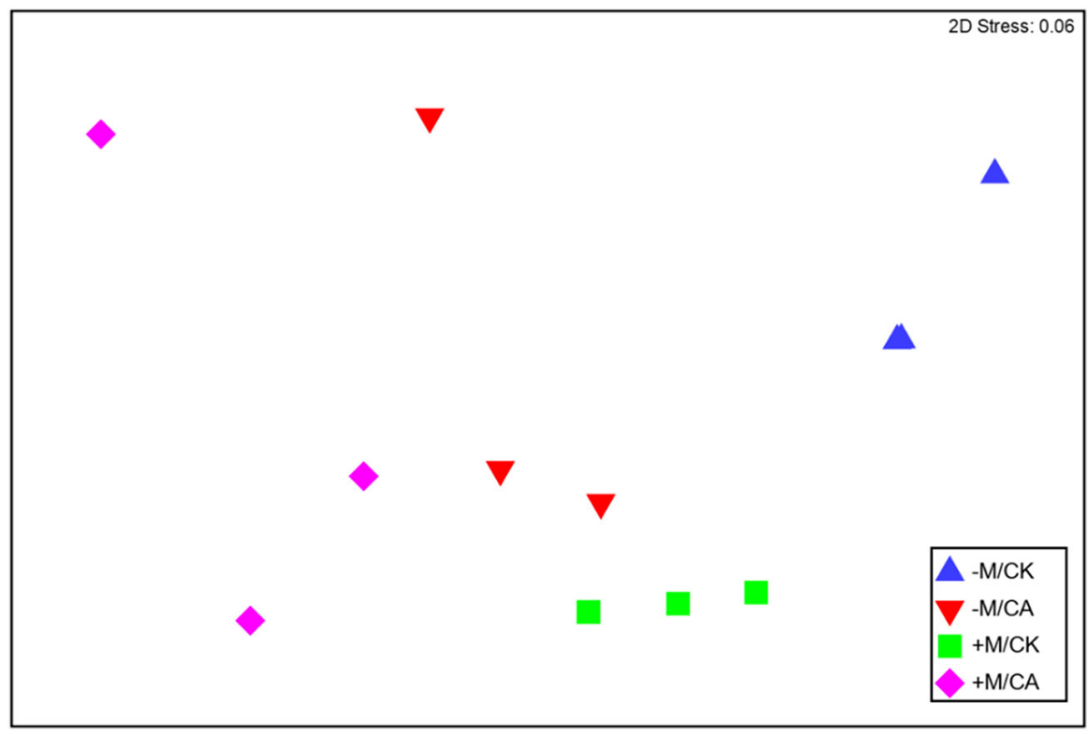

Fig. 3 The non-metric multi-dimensional scaling (NMDS) for soil parameters among treatments 


\section{Discussion}

Low available $\mathrm{P}$ is often observed in highly acidic soils, which may be attributed to phosphate adsorption by minerals and phosphate precipitation as $\mathrm{Fe}$ and $\mathrm{Al}$ phosphates (Barroso and Nahas 2005). Among the treatments, the lowest content of available $\mathrm{P}$ was found in the $-\mathrm{M} / \mathrm{CK}$, which also showed the lowest $\mathrm{pH}$ (Table 1). The content of $\mathrm{AP}$ in $+\mathrm{M} / \mathrm{CK}$ were higher than $-\mathrm{M} / \mathrm{CK}$. Similarly, it was higher in-M/CA than in $-\mathrm{M} / \mathrm{CK}$. These results indicated that AMF and PSB are able to mobilize insoluble soil phosphates, extend their extensive hyphae from the phosphorus depletion zone to explore a greater soil volume for inorganic P sources (Smith and Smith 2011; Rodríguez and Fraga 1999). Castagno et al. (2011) reported the ability of PSB to solubilize phosphate and to promote plant growth. In our study, AGB and UGB were the lowest in -M/CK, consist with that AMF symbiosis contributes significantly to global phosphate and carbon cycling and influences primary productivity in terrestrial ecosystems (Fitter 2005). Soil enzymes are important components of soil microbial activity, participate in many vital soil biochemical reaction, and have important effects on soil fertility (Thomson et al. 2015; Yousuf et al. 2012; Zhang et al. 2016a; Zhu et al. 2012). The beneficial effect of PSB inoculation may be direct due to an increased supply of available $\mathrm{P}$, or indirect through changes in the growth rate and metabolic activities of the crop (Kaur and Reddy 2015). The microbial inoculum of the AMF and PSB had a significant influence on soil acid phosphatase activities (Fig. 2-C). Soil acid phosphatase activities were significantly higher in $+\mathrm{M} / \mathrm{CA}$ in both root and hyphae compartments. Our present results also show that the mineralization of phytate and the amount of bacteria and fungus were significantly enhanced when both AMF and PSB were present in the soil. Previous study found that The AMF trigger PSB growth and activity, Inreturn, the PSB enhanced mineralization of organic $\mathrm{P}$ and the availability for AMF. When additional $\mathrm{P}$ was added to increase soil available P, the PSB enhanced AMF hyphal growth, and PSB activity was also stimulated by the fungus (Zhang et al. 2016b). These results imply that the PSB and AMF play an important role in the mineralization of phytate and plant growth.

Studies found that soil physicochemical properties, as key factors for soil microbes, affect soil microbial community composition and diversity though changing the composition and chemical properties of soil matrix and the efficiency of nutrient use (Yuan et al. 2014; Yao et al. 2014). Soil pH has been recently proved as the major factor to determine the soil microbial activity and composition (Chu et al. 2010; Shen et al. 2013). The relationship between the physicochemical properties and microbial composition of soil and soil biology provides a guide for soil management (Dick et al. 1996). In the present study, the ability of PSB to solubilize insoluble phosphate was related to the soil available $\mathrm{P}$ content. This result agreed with what was reported by Mander et al. (2012). PSB and AMFcan improve plant growth, yield and phosphorus content of several crops, and may be used as bioinoculant to enhance sustainable production (Viruel et al. 2014).

\section{Conclusions}

Here, we examined the remediation effects of AMF and PSB on abandoned solid waste of coal mine. AMF-PSB Combined inoculation were significantly promoted AP, AGB and UGB in root and hyphae compartments. The microbial inoculum of the AMF and PSB had a significant influence on soil acid phosphatase activities. R-AP, H-AP, R-ACP and H-ACP positively influenced the AGB and UGB. AMF and PSB improved plant growth and phosphorus content. PSB enhanced mineralization of organic $\mathrm{P}$ and the availability for AMF. Thus, AMF-PSB could be used as bioinoculant to enhance sustainable production of the plant in abandoned solid waste of coal mine.

Acknowledgements We gratefully acknowledge the State Key Research Development Program of China (Grant No. 2016YFC0501106) and the National Natural Science Foundation of China (Project 51574253).

Open Access This article is distributed under the terms of the Creative Commons Attribution 4.0 International License (http://crea tivecommons.org/licenses/by/4.0/), which permits unrestricted use, distribution, and reproduction in any medium, provided you give appropriate credit to the original author(s) and the source, provide a link to the Creative Commons license, and indicate if changes were made.

\section{References}

Andrade G, Linderman RG, Bethlenfalvay GJ (1998) Bacterial associations with the mycorrhizosphere and hyphosphere of the arbuscular mycorrhizal fungus Glomus mosseae. Plant Soil 202:79-87

Barker DG, Chabaud M, Russo G, Genre A (2017) Nuclear Ca(2+) signalling in arbuscular mycorrhizal and actinorhizal endosymbioses: on the trail of novel underground signals. New Phytol 214:533

Barroso CB, Nahas E (2005) The status of soil phosphate fractions and the ability of fungi to dissolve hardly soluble phosphates. Appl Soil Ecol 29:73-83

Bell T, Newman JA, Silverman BW, Turner SL, Lilley AK (2005) The contribution of species richness and composition to bacterial services. Nature 436:1157-1160

Bi Y (2008) Effects of phosphate-solubilizing bacteria on amendment of coal fly ash. Chin J Environ, Eng, p 018 
Bi Y, Shen H (2019) Effect of micro-reclamation on different planted forest on the vegetation self-succession in the western mining subsidence area. J China Coal Soc 44(01):307-315

Bi Y, Guo J, Liu R (2008) Effects of phosphate-solubilizing bacteria on amendment of coal fly ash. Chin $\mathrm{J}$ Environ Eng 09:1235-1238

Bi Y, Zhang Y, Zou H (2018) Plant growth and their root development after inoculation of arbuscular mycorrhizal fungi in coal mine subsided areas. Int J Coal Sci Technol 5(1):47-53

Bi Y, Xiao L, Sun J (2019a) An arbuscular mycorrhizal fungus ameliorates plant growth and hormones after moderate root damage due to simulated coal mining subsidence: a microcosm study. Environ Sci Pollut Res 26:11053. https://doi.org/10.1007/ s11356-019-04559-7

Bi Y, Zhang J, Song Z, Wang Z, Qiu L, Hu J, Gong Y (2019b) Arbuscular mycorrhizal fungi alleviate root damage stress induced by simulated coal mining subsidence ground fissures. Sci Total Environ 652:398-405

Castagno LN, Estrella MJ, Sannazzaro AI, Grassano AE, Ruiz OA (2011) Phosphate-solubilization mechanism and in vitro plant growth promotion activity mediated by Pantoea eucalypti isolated from Lotus tenuis rhizosphere in the Salado River Basin (Argentina). J Appl Microbiol 110:1151-1165

Chu H, Fierer N, Lauber CL, Caporaso JG, Knight R, Grogan P (2010) Soil bacterial diversity in the Arctic is not fundamentally different from that found in other biomes. Environ Microbiol 12:2998-3006

Dick RP, Breakwell DP, Turco RF, Doran JW, Jones AJ (1996) Soil enzyme activities and biodiversity measurements as integrative microbiological indicators. In: Methods for assessing soil quality (methodsforasses), pp 247-271

Fitter AH (2005) Presidential address: darkness visible: reflections on underground ecology. J Ecol 93:231-243

Hattori T (1985) Kinetics of colony formation of bacteria: an approach to the basis of the plate count method. Reports of the Institute for Agricultural Research-Tohoku University (Japan)

Kaur G, Reddy MS (2015) Effects of phosphate-solubilizing bacteria, rock phosphate and chemical fertilizers on maize-wheat cropping cycle and economics. Pedosphere 25:428-437

Kohler J, Caravaca F, Carrasco L, Roldan A (2007) Interactions between a plant growth-promoting rhizobacterium, an AM fungus and a phosphate-solubilising fungus in the rhizosphere of Lactuca sativa. Appl Soil Ecol 35:480-487

Lam PL (2005) Energy in China: development and prospects. China Perspect 59:14-25

Levy MA, Cumming JR (2014) Development of soils and communities of plants and arbuscular mycorrhizal fungi on west virginia surface mines. Environ Manag 54:1153-1162

Liu J, Diamond J (2005) China's environment in a globalizing world. Nature 435:1179

Liu X, Zhou W, Bai Z (2016) Vegetation coverage change and stability in large open-pit coal mine dumps in China during 1990-2015. Ecol Eng 95:447-451

Mander C, Wakelin S, Young S, Condron L, O’Callaghan M (2012) Incidence and diversity of phosphate-solubilising bacteria are linked to phosphorus status in grassland soils. Soil Biol Biochem 44:93-101

Mar Vázquez M, César S, Azcón R, Barea JM (2000) Interactions between arbuscular mycorrhizal fungi and other microbial inoculants (Azospirillum, Pseudomonas, Trichoderma) and their effects on microbial population and enzyme activities in the rhizosphere of maize plants. Appl Soil Ecol 15:261-272

Miao Z, Marrs R (2000) Ecological restoration and land reclamation in open-cast mines in Shanxi Province. China J Environ Manag 59:205-215
Mukhopadhyay S, Maiti SK, Masto RE (2014) Development of mine soil quality index (MSQI) for evaluation of reclamation success: a chronosequence study. Ecol Eng 71:10-20

Mukhopadhyay S, Masto RE, Yadav A, George J, Ram LC, Shukla SP (2016) Soil quality index for evaluation of reclaimed coal mine spoil. Sci Total Environ 542(Pt A):540-550

Olsen S, Sommers L, Page A (1982) Methods of soil analysis. Part 2. Chemical and microbiological properties of Phosphorus. ASA Monogr 9:403-430

Pedrol N, Puig CG, Souza P, Forján R, Vega FA, Asensio V, Andrade L (2010) Soil fertility and spontaneous revegetation in lignite spoil banks under different amendments. Soil Tillage Res 110:134-142

Pérez E, Sulbarán M, Ball MM, Yarzábal LA (2007) Isolation and characterization of mineral phosphate-solubilizing bacteria naturally colonizing a limonitic crust in the south-eastern Venezuelan region. Soil Biol Biochem 39:2905-2914

Rodríguez H, Fraga R (1999) Phosphate solubilizing bacteria and their role in plant growth promotion. Biotechnol Adv 17:319

Sabannavar SJ, Lakshman HC (2009) Effect of rock phosphate solubilization using mycorrhizal fungi and phosphobacteria on two high yielding varieties of Sesamum indicum L. World J Agric Sci 5:470-479

Sashidhar B, Podile AR (2010) Mineral phosphate solubilization by rhizosphere bacteria and scope for manipulation of the direct oxidation pathway involving glucose dehydrogenase. J Appl Microbiol 109:1-12

Shen C, Xiong J, Zhang H, Feng Y, Lin X, Li X, Chu H (2013) Soil $\mathrm{pH}$ drives the spatial distribution of bacterial communities along elevation on Changbai Mountain. Soil Biol Biochem 57:204-211

Singh AN, Singh JS (2006) Experiments on ecological restoration of coal mine spoil using native trees in a dry tropical environment, India: a synthesis. New Forest 31:25-39

Sinha S, Masto RE, Ram LC, Selvi VA, Srivastava NK, Tripathi RC, Van Hees P (2009) Rhizosphere soil microbial index of tree species in a coal mining ecosystem. Soil Biol Biochem 41:1824-1832

Smith SE, Smith FA (2011) Roles of arbuscular mycorrhizas in plant nutrition and growth: new paradigms from cellular to ecosystem scales. Annu Rev Plant Biol 62:227

Staddon PL, Fitter AH, Graves JD (2010) Effect of elevated atmospheric $\mathrm{CO} 2$ on mycorrhizal colonization, external mycorrhizal hyphal production and phosphorus inflow in Plantago lanceolata and Trifolium repens in association with the arbuscular mycorrhizal fungus Glomus mosseae. Glob Change Biol 5:347-358

Thomson BC, Tisserant E, Plassart P, Uroz S, Griffiths RI, Hannula SE, Veen JAV (2015) Soil conditions and land use intensification effects on soil microbial communities across a range of European field sites. Soil Biol Biochem 88:403-413

Tripura C, Sashidhar B, Podile AR (2007) Ethyl methanesulfonate mutagenesis-enhanced mineral phosphate solubilization by groundnut-associated Serratia marcescens GPS-5. Curr Microbiol 54:79-84

Trouvelot A, Kough JL, Gianinazzipearson V (1986) Mesure du taux de mycorhization VA d'un systeme radiculaire. Recherche de methodes d'estimation ayant une signification fonctionnelle. Paper presented at the Physiological and Genetical Aspects of Mycorrhizae $=$ Aspects Physiologiques Et Genetiques Des Mycorhizes: Proceedings of the European Symposium on Mycorrhizae Dijon, 1-5 July 1986

Viruel E, Erazzú LE, Martínez Calsina L, Ferrero MA, Lucca ME, Siñeriz F (2014) Inoculation of maize with phosphate solubilizing bacteria: effect on plant growth and yield. J. Soil Sci Plant Nutr 14:819-831 
Xiao L, Bi Y, Du S, Wang Y, Guo C (2019) Effects of re-vegetation type and arbuscular mycorrhizal fungal inoculation on soil enzyme activities and microbial biomass in coal mining subsidence areas of Northern China. CATENA 177:202-209

Yao M, Rui J, Li J, Dai Y, Bai Y, Heděnec P, Liu C (2014) Ratespecific responses of prokaryotic diversity and structure to nitrogen deposition in the Leymus chinensis steppe. Soil Biol Biochem 79:81-90

Yousuf B, Keshri J, Mishra A, Jha B (2012) Application of targeted metagenomics to explore abundance and diversity of $\mathrm{CO}_{2}$-fixing bacterial community using cbbL gene from the rhizosphere of Arachis hypogaea. Gene 506:18-24

Yuan Y, Si G, Wang J, Luo T, Zhang G (2014) Bacterial community in alpine grasslands along an altitudinal gradient on the Tibetan Plateau. FEMS Microbiol Ecol 87:121-132

Zeng Q, An S, Liu Y (2017) Soil bacterial community response to vegetation succession after fencing in the grassland of China. Sci Total Environ 609:2-10
Zhang L, Fan J, Ding X, He X, Zhang F, Feng G (2014) Hyphosphere interactions between an arbuscular mycorrhizal fungus and a phosphate solubilizing bacterium promote phytate mineralization in soil. Soil Biol Biochem 74:177-183

Zhang C, Liu G, Xue S, Wang G (2016a) Soil bacterial community dynamics reflect changes in plant community and soil properties during the secondary succession of abandoned farmland in the Loess Plateau. Soil Biol Biochem 97:40-49

Zhang L, Xu M, Liu Y, Zhang F, Hodge A, Feng G (2016b) Carbon and phosphorus exchange may enable cooperation between an arbuscular mycorrhizal fungus and a phosphate-solubilizing bacterium. New Phytol 210(3):1022-1032

Zhang H, Xu W, Li Y, Lyu J, Cao Y, He W (2017) Changes of soil microbial communities during decomposition of straw residues under different land uses. J Arid Land 5:666-677

Zhu B, Dijk GV, Fritz C, Smolders AJP, Pol A, Jetten MSM, Ettwig KF (2012) Anaerobic oxidization of methane in a minerotrophic peatland: enrichment of nitrite-dependent methane-oxidizing bacteria. Appl Environ Microbiol 78:8657-8665 